\title{
Transferability of European Flood Impact Estimation Techniques to the Yangtze River Catchment and Possible Adaptations*
}

\author{
Marco GEMMER
}

(Canter for International Development and Environmental Research and

Department of Geography, Justus Liebig University, Giessen, Germany)

\begin{abstract}
European flood impact estimation techniques is given. The questions how to handle flood hazards and how to minimise losses due to floods are highlighted. It can be noted, that the estimation of flood risks and the assessment of potential losses due to floods is a great demand for the Yangtze River catchment but European flood impact estimation techniques are hardly transferable. Therefore, an integrated modelling approach combining hydrodynamic and unit flood damage models are introduced.
\end{abstract}

Keywords: flood hazards, flood impact estimation, flood inundation estimation, flood damage, damage curves, unit flood damage

Technical or structural flood protection was the basis of defending people from flood both in Europe and China, and all over the world, during the last centuries ${ }^{[1-3]}$. Within the last decades, the awareness has arisen that structural measures of flood protection can not be the sustainable and competitive means of protecting the people from floods ${ }^{[4-6]}$. Though structural flood measures such as dykes, flood diversion areas, or wider profiles is giving a certain degree of flood safety up to a designed flood level ${ }^{[7-9]}$, there is a latently endangerment behind or under the technical flood protection measure. Moreover, changes in the hydrological regimes of a river demand a costly adaptation of these measures.

Precipitation as the main reason for floods at the Yangtze River can be regarded as being underlying positive and negative trends. Latest studies on precipitation in the Yangtze River catchment indicate a tendency towards a concentration of summer rainfalls within a shorter time period. The relevance of this trend for future flood events is apparent ${ }^{[10]}$ and underlines results from recent studies which depict an increase of both amplitude and frequency of floods in future [11] Since the analysis of extreme events in both observations and coupled models is underdeveloped and the changes in frequency of extreme events cannot be generally attributed to the human influence on global climate ${ }^{[12]}$, more emphasis should be placed on the estimation of flood impacts

* Received: 2002-08-01;Accepted:2003-11-23.Marco GEMMER, male, Born 1975, Ph.D.email: Marco.Gemmer@geogr.uni-giessen.de. 
in the floodplain. European flood impact estimation techniques are hardly transferable due to the very special data availability, hydrological characteristics, and economic background in the Yangtze River catchment.

\section{Handling of Flood Hazards}

The design flood protection measures in Germany are based on flood frequencies which are determined statistically, e.g. by flood experiences ${ }^{[13]}$. This flood potential is the basis for the estimation of flood-prone areas and potential losses. If the consequences of floods are known, the handling of flood risks can be determined ${ }^{[14]}$. This enhances the ability of flood risk management to inform the inhabitants of flood-prone areas about the flood risks and the decision makers to find adapted non-structural flood measures ${ }^{[15]}$. "Flood protection systems have been designed and operated based on the assumption of stationarity of hydrological processes of river stage or discharge. If this assumption is incorrect then the existing design procedures for embankments, dams, reservoirs, relief channels, polders, etc. will have to be revised ${ }^{[16]}$. Therefore, the planning and construction of flood diversion areas will be inevitable in order to face the new threats in the $1.8 \times 10^{9} \mathrm{~km}^{2}$ sized Yangtze river catchment, even is the TGP is completed. This counts especially for the tributaries of the Yangtze River since flood events never cover the entire Yangtze River catchment. Finding the best means and ways of flood protection, several compromises between technical feasibility, economical rationality, political enforceability, and ecological compatibility have to be made ${ }^{[17]}$.

The area along the middle reaches of the Yangtze River is underlying a tremendous economic and social development. The flood-prone areas ask for a high standard of flood protection but the planning of this measure is separated from the development process and concentrates on the hydro-meteorological forecasts (operational flood defence), and the technical flood protection. The quantification of people's endangerment towards floods in the embanked areas along the Yangtze channel is very difficult since the endangerment varies with the kind of flood (e.g. flash flood or summer flood), the time of the onset of the flood, the predictability of the flood, and the ability of civil flood protection forces to cope with the flood. At the Yangtze River, another flood risk has to be considered. It is the possibility of a man-made flooding of cultivated land as part of a complex flood protection system for the urban centres at the main channel such as Wuhan or Jingzhou (Shashi). Many of the flood diversion polders are densely populated today. They are inhabited by 6 million people and cover an area of $12000 \mathrm{~km}^{2}$. One restricting aspect of implementing the official flood protection plans is the increasing urbanisation and agricultural development in the officially designated polder areas. Socio-economic development demands a functioning flood protection but also limits the conversion of the planning. Therefore, the means of preventive flood protection such as minimisation of losses by flood (area) management or pre-flood activities ${ }^{[18]}$ can not be adopted at all areas. The questions that intrude is (i) how to assess the flood risk, (ii) how to assess the monetary losses, and (iii) how to give Decision Support in Land Use Planning for flood-prone areas and how to implement information of flood risk 
zones in Flood Management.

\section{Flood Damage Estimation}

The estimation of potential flood damage is essential for long-term flood prevention planning and emergency management ${ }^{[19]}$ and real-time loss estimation ${ }^{[20]}$. Flood damage potentials increase with the accumulation of economic values although flood control measures might have effect simultaneously. The application of the flood loss estimation results range from structural to non-structural measures.

Structural flood protection measures have to be assessed monetarily in order to design a benefit-costs equation. It is comparatively easy to calculate the costs for the construction of primary, secondary, and safety dykes. The direct opposite happens for the costs when using a flood diversion area or an embanked polder area as part of structural flood protection e.g. in Hubei province.

The elementary challenge is the handling of benefits and costs of flood protection measures at the Yangtze River. Examples are the 1998 and 2002 flood events ${ }^{[1,21]}$. Moreover, the benefit of flood protection measurements might take effect hundreds of kilometres downstream the location of the flood protection manoeuvre. During this decision making process, technological, hydraulic, geo-technical, environmental, and economic factors have to be considered simultaneously ${ }^{[22]}$.

Therefore, the monetary assessment of flood-prone areas in the Yangtze River catchment forces on. Following the processes of development and urbanisation in the floodplains need at least the same attention as geomorphological, hydrological and hydraulic processes in the frame of floodplain processes discussion. First of all, monetary losses in flood diversion areas have to be investigated, since the costs of the use of flood diversion areas is heavily discussed in China ${ }^{[1]}$ but flood diversion is indispensable for the comprehensive utilisation of the Yangtze river catchment. If the cost effectiveness of using a flood diversion area is known, a comparison of these polders can be reached and balanced with the benefits of the flood protection measures. Moreover, a comparison of embanked polders can be carried out. Such a comparison might have led to a different procedure of opening secondary dykes at the Yangtze during the 1998 flood event. Making a decision of which area to evacuate and which persons to affect is socially and politically sensitive. Actually, the decision making process is emotionally managed.

\subsection{Flood Inundation Depth}

Water stage calculations can model extreme flood events. Tools are 1-, 2- or 3-dimensional flow equations. The simulation of water stages needs coefficients for the calibration of the model in order to approach the real physical process. At present, both in Germany, and in whole western Europe, the planner's and official's demand for data on potential flood areas and economical losses can be accommodated by a quickly developing information technology both on hardware and software sectors, which also deliver a better basis and quality of ground data and mathematical calculations.

In Germany, scientific and public institutions and public companies focus on the basis of esti- 
mating flood areas and flood damages ${ }^{[23]}$. The most common is the "Working Group of the Federal States on Water Problems" (Länderarbeitsgemeinschaft Wasser, LAWA), the "Working Group on Flood Potentials" of the Bund der Ingenieure für Wasserwirtschaft, Abfallwirtschaft und Kulturbau ${ }^{[7]}$. Especially the German provinces ("Bundeslaender") force the estimation of potential flood areas and losses, although there is no governmental specification, which handles for example the protection of buildings in flood-prone areas ${ }^{[24]}$. Many of them started key-projects, which focus either on the collection of flood data for the calculation of flood damage curves, or on the generating of data from standardised data and statistical models. Examples are HWINFO of the Wasserwirtschaftsverwaltung Rheinland-Pfalz, HOWAS of the Bayerisches Landesamt für Wasserwirtschaft, and HWS of the Ministerium fuer Umwelt und Naturschutz, Landwirtschaft und Verbraucherschutz des Landes Nordrhein-Westfalen.

The data are based on real-time flood events. In the meanwhile, results from this scientific inform residents about the flood risk and flood potentials in their area and strategies to reduce losses are given ${ }^{[9,25-26]}$. There are also institutions which work over political boundaries for flood research such as the International Commission for the Hydrology of the Rhine Basin (CHR). This organisation developed DEFLOOD (Development of Methodologies for the Analysis of the Efficiency of Flood Reduction Measures in the Rhine Basin on the Basis of Reference Floods) which analyses the effects of flood retention under different scenarios. Another one is the International Commission for the Protection of the Rhine (ICPR) which draws the attention of the citizens affected along the Rhine and in the Rhine valley to residual risk by it's newly developed Rhine Atlas ${ }^{[25]}$. Another institution working Europe-wide is the Natural Hazard Unit of the European Commission's Joint Research Centre which developed LISFLOOD-FP, a model for dynamic flood simulation at European rivers ${ }^{[27-29]}$. Other packages are TOPMODEL or MIKE-SHE. Most of the software packages work with the channel geometry and need cross-sections. They are mainly applied in meso-scale catchments or short river sections $(5-50 \mathrm{~km})$ only and use real-time flood data.

Assessing real flood events such as 1998 or 1954 has several advantages, since spatial-temporal processes and information can be measured and describe and every event has got it's own reference scale. However, real flood events show just a limited sector of the possibilities and are only valid for this event. Moreover, required data often is inaccessible. Therefore, the prediction of data and facts has more advantages. It can help to minimise the losses before a flood is going to happen. The prediction of data does not mean, that exact water levels and monetary losses can be forecasted, because values are changing every year and the predicted flood event will never happen as simulated on the computer. But the prediction of data can deliver scales of possible losses and the possibility to compare different areas.

In the author's current research, the determination of the flood inundation depth is accomplished by a raster-based model which represents floodplain hydraulics such as flow velocity to a minimum in order to predict inundation depths integrated in a GIS. Flood Area of Heidelberg's Geomer company was chosen as the adequate tool for this operation. The advantages of the ras- 
ter-based flood inundation model are, besides above mentioned, the ability of dynamic linking with the loss model.

Both one-dimensional models and two-dimensional models are computationally demanding and require a certain level of experiences from the user. Since the aim of hydraulic modelling is inundation depth, the modelling of velocities and other variables can be regarded as redundant. Secondly, the input data on topography restricts the computationally and data demanding two-dimensional modelling and the one-dimensional modelling since cross-sections are not available for the Yangtze river since the topographic domain can easily be changed due to high sedimentation and the pluvial regime of the Yangtze river. Moreover, distributed validation data are not available but essential. All of these factors count even more for three-dimensional models ${ }^{[30]}$. Therefore, it is more beneficial to embed a model which is easier for the handling and capable of treating the available data.

\subsection{Loss estimation}

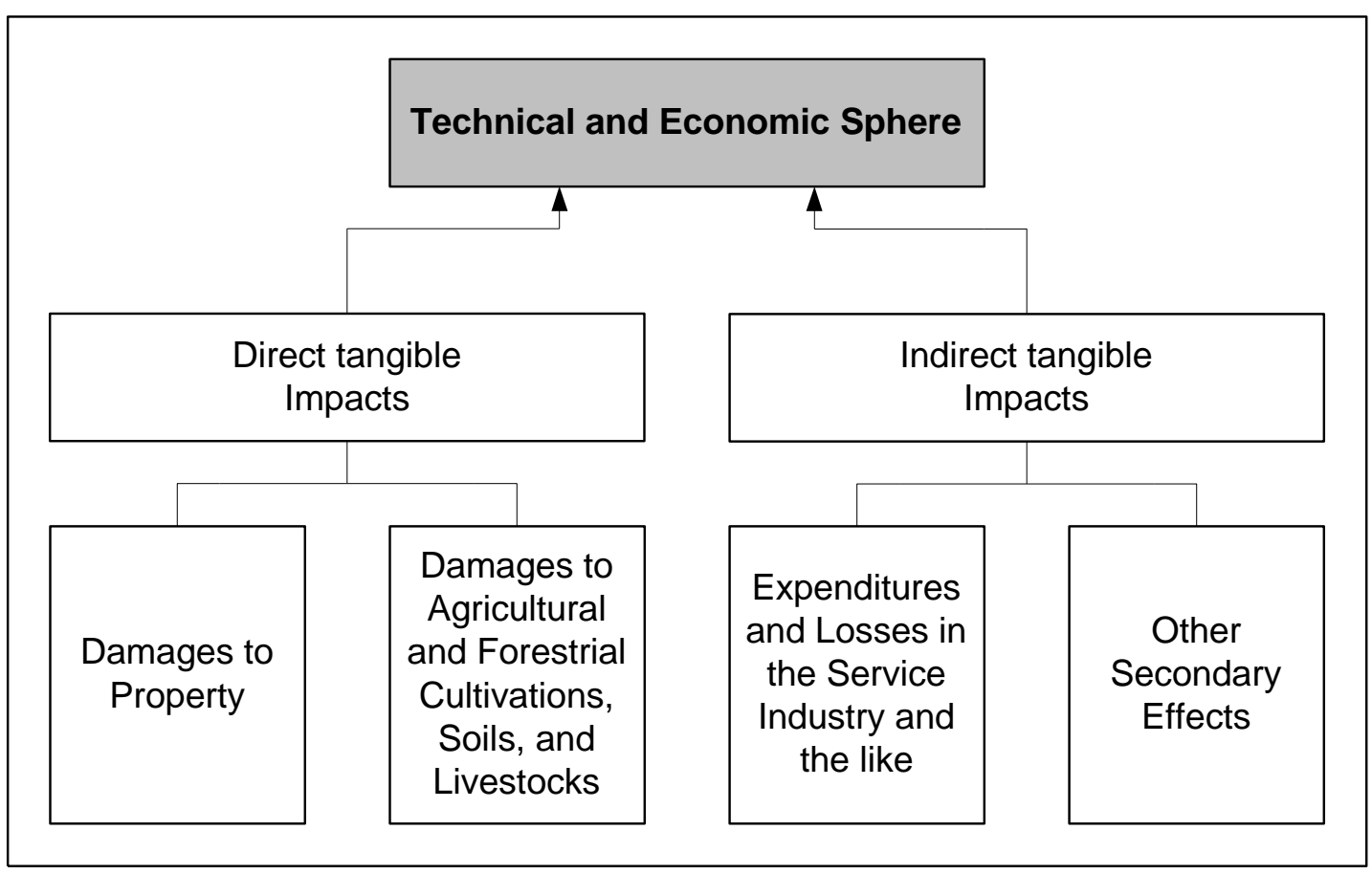

Fig. 1 Effects and Impacts of Floods on the Technical and Economic Sphere

If the economic effects of floods are supposed to be minimised by flood control measures, the analysis of the status quo of potential losses has to be enforced. Following BWKand SCHMIDTKE ${ }^{[7,31]}$, three approaches depending on the data availability can be applied for this analysis: (i) the micro-scale method with data from empirical studies on real estates or Lear's, (i) the meso-scale method with data from economic statistics, land use on Lear's basis, and topographical units, (iii) the macro-scale method with data from large scale coherent land use units such as communities.

At present, the meso-scale approach for the analysis of potential losses is the most common in 
Germany but will be replaced by the micro-scale approach in near future ${ }^{[7]}$. This is due to the good availability of data in this context. Data of the "amtliche topograpgisch-kartographische Informationssystem" (ATKIS), the official cadastre-maps, or real-estate information can be utilised for the detection of the land use.

Usually, the flood simulation and the losses are calculated for different return periods. Since the hydrological and structural situation is different in China due to the varying hydrological contexts with changing flood discharges and water levels, the analysis of different return periods is impracticable.

The effects of floods on the technical and economic sphere are displayed in figure 1 whereas two main categories are classified: tangible and intangible damages to the technical and economic sphere. Tangible damages can be monetarily assessed and further categorised as direct and indirect impacts. Damages with direct tangible impact on our sphere rise for example by direct contact to the flooding water, by erosion, or deposition of sediments. Indirect tangible losses are first of all not obvious and may be caused by business interruptions. Examples for direct and indirect damages due to flooding are given in Table 1.

Tab. 1 examples for direct and indirect tangible damages due to flood

\begin{tabular}{|c|c|c|c|}
\hline \multicolumn{2}{|c|}{ Direct tangible Damages } & \multicolumn{2}{|c|}{ Indirect tangible Damages } \\
\hline Damages to Property & $\begin{array}{l}\text { Damages to Agricultural and } \\
\text { Forestall Cultivation, Soils, } \\
\text { and Livestock }\end{array}$ & $\begin{array}{l}\text { Expenditures and Losses in } \\
\text { the Service Industry and the } \\
\text { like }\end{array}$ & Other Secondary Effects \\
\hline Private residential area & $\begin{array}{l}\text { Crop (arable land, irrigated } \\
\text { land, non-irrigated land, } \\
\text { special cultures) }\end{array}$ & Disaster control & $\begin{array}{l}\text { Productivity in Industry } \\
\text { and Agriculture }\end{array}$ \\
\hline $\begin{array}{l}\text { Public area (buildings \& } \\
\text { grounds) }\end{array}$ & Forest industry & rol measures & Supplying In \\
\hline $\begin{array}{l}\text { Commerce, trade \& in- } \\
\text { dustry }\end{array}$ & Eroded areas & Traffic (road blocks, etc.) & $\begin{array}{l}\text { Reduction of prices for } \\
\text { Houses and Ground }\end{array}$ \\
\hline $\begin{array}{l}\text { Agricultural buildings, } \\
\text { grounds, and warehouses }\end{array}$ & Livestock & $\begin{array}{l}\text { Losses due to cutting off } \\
\text { hydropower plants }\end{array}$ & $\begin{array}{l}\text { Negative Effects for } \\
\text { Tourism }\end{array}$ \\
\hline $\begin{array}{l}\text { Infrastructure (traffic, } \\
\text { supply grid) }\end{array}$ & Polluted soils & Losses due to power-cuts & $\begin{array}{l}\text { Loss of Recreation Ar- } \\
\text { eas }\end{array}$ \\
\hline
\end{tabular}

The guideline for planners in Germany recommends to use a micro-scale field check of the flood-prone objects but also depicts that the quantity of the field check can decrease with the size of the research are ${ }^{[7]}$. Imprecision of damage classes for increasing flood inundation is acceptable due to the digressive course of the most damage functions ${ }^{[7]}$.

Losses due to damages at objects, fixed inventory, and flexible inventory have to be summarised. Usually, these losses can be assessed by assuming total losses, costs for new acquisition, or costs for cleaning of the objects. Also, data of the fire insurance companies can be considered. 
Guidelines for the planning and construction of residential objects in flood-prone areas are provided by the government ${ }^{[24]}$. Also, a competence centre for damages at buildings due to flood was set-up by the BVBW.

\subsection{Damage Functions}

Damage functions characterise the coherence between monetary flood losses based on land use classes and parameters of the floods such as inundation depth or spatial and temporal distribution of the inundation ${ }^{[7]}$. For different areas with different return periods of floods, damage functions are not necessarily transferable. Moreover, damage functions are assessed by different authorities and not necessarily based on the same standards. Generally speaking, two approaches are widely accepted for the estimation of flood impacts: the first is based on the unit loss model and the second on the linkage effects ${ }^{[20]}$. The unit loss model implies a property-by-property assessment of potential damage and has been modified in different countries. An example is the HOWAS database which has been described above. Other approaches imply postcodes, address-by-address flood loss estimation or data of insurance companies such as the fire insurance companies ${ }^{[32]}$. However, the estimation of flood losses by these means and ways is limited to areas which have experienced floods in recent years or urban areas with a high insurance density.

For the Yangtze region as a whole, there is no standardised methodology for flood damage estimation. But it is indispensable for the development of damage functions to create a land use referenced damage. In some cases, statistic data are not surveyed on the land use basis but on administrative conditions ${ }^{[7]}$. The same problem is conformable in China ${ }^{[1,33]}$ The design of the inundation depth classes at the Rhine river for example follows international guidelines ${ }^{[25]}$ and can be seen in table 2 . The explanatory statement is based on the flood experiences at the Rhine river.

Tab. 2 Design of the Inundation Depth Classes at the Rhine river

\begin{tabular}{cc}
\hline Classification & Inundation class for embanked areas $(\mathrm{m})$ \\
\hline Low inundation & $<0.5$ \\
Moderate inundation & $0.5-2.0$ \\
High inundation & $2.0-4.0$ \\
$\sim$ & $4.0-6.0$ \\
$\sim$ & $6.0-8.0$ \\
\hline
\end{tabular}

\section{Demands of Flood impact estimation models}

A great demand for the Yangtze River catchment is the estimation of flood risks and the assessment of potential losses due to floods. This might be a part of preventive flood protection planning at the Yangtze River in future and from this, a decision support system for the handling of flood risks could be derived. This leads to the assumption, that the flood risk at the Yangtze River has to be accepted, but losses due to this flood risk can be abated.

An integrated modelling approach has to be undertaken in order to follow the needs of the actual Flood Management in China. This can be reached by combining a GIS-based hydrodynamic 
model for flood depth estimation with flow propagation and a GIS-, and RS-based unit flood damage model with different tangibles of flood damages. Both models need to work on raster-base. The advantage of the raster-based model is the ability of dynamic linking both models.

Another demand for future studies is the format and quality of data which have to be used in flood relevant concerns. Since the morphological floodplain is an area which is not bordering administrative boundaries, data availability is poor and many socio-economic data have to be generated for floodplain the assessment. Another matter of concern is the availability of spatial data like elevation or river cross sections. Geographical techniques implemented in a Geographical Information System (GIS) can find a remedy. A GIS-based approach solving the defined problem is encouraged by citing WATKINS and MCKINNEY ${ }^{[34]}$, since "GIS is an especially appealing technology for DSSs because it can be used not only for information management, but also for spatial analysis and the visualisation of model output. Thus, a GIS by itself could function as a DSS, provided that spatial analyses alone provided adequate support in the decision making process".

Spatial analysis of floodplains can simplify the matters of deciding which and how to use flood diversion areas or opening embanked polders. The remaining problem is, that this approach underlines a general trend which confronts decision makers with new tools and techniques in their fields ${ }^{[35]}$, but the proper use of this techniques can not be carried out by the decision maker himself. Therefore, the results of spatial analysis have to be displayed on an external user-friendly platform which asks to be developed.

Based on Turban the design of a DSS forces on, since “... a decision support system can improve the quality of the information on which the decision is based (and consequently the quality of the decision) by providing not only a single solution but a range of alternate solutions. Decision support may consist of "any and all data, information, expertise or activities that contribute to option selection ${ }^{[36]}$.

A DSS designed for Yangtze River flood protection planning and measurements could improve the quality of decisions with an optimum of benefit and minimum of costs of the solution which are invented, developed, analysed, and provided by the DSS. More informed decision-making can be facilitated by providing flood decision makers with an environment that enables them to review spatial data and study effects of potential decisions.

\section{Outlook}

The impacts of climate change on Yangtze river flooding conditions requires further quantitative analyses, e.g. by simulating the climatological-hydrological system in an integrated model ${ }^{[37]}$. Until this goal is reached, the author will carry out the assessment of flood prone areas at the Yangtze as part of the identification of risks. It will be the backbone for the handling of flood risks and for the bringing of the perceptions of the flood handling into practice. The results will show the cost effectiveness of the flood protection measure and hereby follow guidelines which are described in LAWA and Rother, especially the minimisation of flood risks, the strengthening 
of the awareness of the flood risk, and the advances of flood information.

Flood loss estimations are supposed to combine both flood hazard and vulnerability data. If this risk information is provided, the flood hazard probability will be reduced. Therefore, a system will be defined, that can provide information on potential flood potentials for political decision makers and the public, and a comparative decision making process with standardised methods for flood authorities.

GIS will be used as a function-platform to the extraction of decision-supporting data. DSS have been successfully designed in further environmental studies, e.g. within the GLOWA-Danube project as a transdisciplinary communication platform ${ }^{[38]}$. Therefore, the aim of further studies is to design a taxonomy for a Decision Support Framework (DSF) based on the very special regards to flood hazards and flood protection planning and measurements at the Yangtze river. This DSF is designed as a basis for the establishment of a DSS which integrates geographical techniques and aids in the selection of different solutions provided. The first of several components included in the DSS should be an environment for reviewing spatial data layers and calculations as maps and graphs, a data repository for large amounts of pertinent data, and methods for reviewing results of "what-if" scenarios concerning flooding a flood diversion area. The studies will make extensive use of GIS in determining the relationship between a flood event and the damage caused by that event. European flood impact estimation techniques will be tested and transferred after a fundamental reorganisation of input data for the Yangtze catchment and a GIS-based acquisition of data which are needed for this transfer.

\section{References}

GEMMER M. Hochwasserschutz und Landnutzungsaenderungen am Yangtze-Mittellauf, VR China. S atellitenbilddokumentierte Entwicklung der Metropole Wuhan und des Jingjiang-Hochwasserrueckhaltebeckens als Beispiel für die wachsende Bedeutung und limitierte Umsetzbarkeit einer bestehenden Hochwasserschutzplanung. Department of Geography, Justus Liebig University, Giessen. 2000. (In German) Schmidt M. Flood and Flood Prevention in Germany 850-1850. In: Toensmann F, Koch M, eds. River Flood Defence Volume 1 B37-B42. Kassel Reports of Hydraulic Engineering No. 9/2000, 2000, Vol. 2. Herkules Verlag, Kassel

3 Wang Z Y. History of Flood Defence in China-with Particular Reference to the Yellow River. In: Toensmann F, Koch M, eds. River Flood Defence: Volume 1: B11-B25. Kassel Reports of Hydraulic Engineering Herkules Verlag, KASSEL, 2000. (9)

4 Kleeberg H B. Extreme Hochwasser-Ursachen und Einfluesse. In: KoENGETER J. ed. 25. IWASA. Internationales Wasserbau-Symposium Aachen 1994/95: Hochwasser-Naturereignis oder Menschenwerk. Mitteilungen des Lehrstuhls und Instituts fuer Wasserbau und Wasserwirtschaft, 1997. No. 104: 89-116. Verlag Mainz, Aachen. (In German)

5 Plate E J. Flood Risk and Flood Management. In: Bronstert A, Bismuth C, MenZel L, eds. European Conference on Advances in Flood Research -Proceedings. PIK: 2000

6 SAMuels P G. Ribamod. River Basin Modelling, Management and Flood Mitigation. Final Report. Report SR 551. HR Wallingford, UK. 1999

7 BWK.Hochwasserschadenspotenziale. Bund der Ingenieure fuer Wasserwirtschaft, Abfallwirtschaft und Kulturbau(BWK) e V, ed. Berichte 1/2001. BMW-Bundesgeschaeftsstelle, Duesseldorf,2001.(In German) 
8 Kleeberg H B, RotHeR K H. Hochwasserflaechenmanagement in Flusseinzugsgebieten. Wasser und Boden, 1996,48 (2): 24-32. Westermann, Braunschweig. (In German)

9 LAWA. Leitlinien fuer einen zukunftseisenden Hochwasserschutz. Hochwasser-Ursachen und Konsequenzen. Laenderarbeitsgemeinschaft Wasser (LAWA), Stuttgart. 1995. (In German)

Becker S, Gemmer M, JIANG T. Precipitation Trends in the Yangtze River Catchment. Proceedings of the International Symposium on Climate Change (ISCC). Beijing, 2003

11 IPCC (Intergovernmental Panel on Climate Change).Climate Change 2001. The Scientific Basis Cambridge. Cambridge University Press, 2001

12 IPCC (Intergovernmental Panel on Climate Change). Climate Change 2001. Overview of Impacts, Adaptation, and Vulnerability to Climate Change. Cambridge: Cambridge University Press, 2001

13 DVWK. Wahl des Bemessungshochwassers. Deutscher Verband fuer Wasserwirtschaft und Kulturbau e.V., Merkblätter zur Wasserwirtschaft 1989, No. 209: Verlag Paul Parey, Hamburg und Berlin. (In German)

14 WBGU. Welt im Wandel: Wege zu einem nachhaltigen Umgang mit Suesswasser. Jahresgutachten 1997. Der Wissenschaftliche Beirat der Bundesregierung Globale Umweltveränderungen (WBGU, German Advisory Council on Global Change). Springer, Berlin, 1998. (In German)

WBGU. Welt im Wandel: Strategien zur Bewältigung globaler Umweltrisiken.Jahresgutachten 1998. Der Wissenschaftliche Beirat der Bundesregierung Globale Umweltveränderungen (WBGU, German Advisory Council on Global Change). Springer, Berlin, 1999. (In German)

Kundzewicz Z B. Floods in the context of climate change and variability. In: Beniston M, ed. Advances in Global Change Research. Kluwer, Dortrecht, Boston, London: 2002.(10): 225-247

Report No. 65: 260-273. Potsdam Institute for Climate Impact Research, Potsdam. RULAND, 1997

18 Samuels P G . An Overview of Flood Estimation and Flood Prevention. In:Toensmann F \& Koch M eds. River Flood Defence Volume 1: G1-G11. Kassel Reports of Hydraulic Engineering ,2000, 9( 2). Herkules Verlag, Kassel.

19 NRC. The Impacts of Natural Disasters. A Framework for Loss Estimation. Natural Research Council (NRC), Washington: National Academy Press, 1999

20 Dutta D, Herath S, Musiake K. A Mathematical Model for Flood Loss Estimation. Journal of Hydrology, 2003, 277: 24-49

21 King L, Gemmer M, Wang R. Hochwasserschutz und Landnutzung am Yangtze. Geographische Rundschau, 2001,53 (10): 28-34

22 Ahmad S, Simonovic S P. Integration of heuristic knowledge with analytical tools for the selection of flood damage reduction measures. Canadian Journal of Civil Engineering, 2001, 28: 208-221

23 Bayene M. Abschaetzung von Hochwasserschadenspotentialen - ein Beitrag zum nachhaltigen Hochwasserschutz. In: Deutsch M, Poertge KH, Teltscher H, eds. Beitraege zum Hochwasser/Hochwasserschutz in Vergangenheit und Gegenwart: Erfurter Geographische Studien 2000, No. 9: 219-236. Institut fuer Geographie der Paedagogischen Hochschule Erfurt, Erfurt. (In German) BVBW.Hochwasserschutzfibel-Planen und Bauen von Gebaeuden in hochwassergefaehrdeten Gebieten. Bundesministerium für Verkehr, Bau -und Wohnungswesen (BVBW), Berlin. 2002. (In German)

ICPR: Uebersichtskarten der Ueberschwemmungsgefaehrdung und der moeglichen Vermoegensschaeden am Rhein. Abschlussbericht zur Vorgehensweise für die Ermittlung der hochwassergefährdeten Flächen und der möglichen Vermögensschäden. International Commission for the Protection of the Rhine, Koblenz. 2001.(In German)

MURL. Potentielle Hochwasserschaeden am Rhein in NRW. MURL, Ministerium fuer German), 2000

De Roo, A P J , Odijk M, et al .Using the LISFLOOD model to simulate floods in the Oder and the Meuse catchments. In: Bronstert A, Bismuth C, Menzel L, eds. European Conference on Advances in Flood Research - Proceedings. PIK Report 2000 , 
Potsdam Institute for Climate Impact Research, Potsdam, No. 65: 518-532

De Roo, A P J, Van Der Knijff J, et al. A simple floodplain inundation model to assist in floodplain management. In: Maione U, Majone-Lehto B, Monti R, eds. New trends in water and environmental engineering for safety and life. Balkema: The Netherlands. 2000

30 Horritt M S, Bates P D. Predicting floodplain inundation: raster-based modeling versus the finite-element approach. Hydrological. Processes, 15: 825-842 Wiley, Chichester. ICPR. ICPR Rhine Atlas 2001. International Commission for the Protection of the Rhine, Koblenz. (In German) :2001

31 Schmidtke R F. Hochwasserschadenspotentiale. In: Bayerisches Landesamt fuer Wasserwirtschaft ed. Extreme Naturereignisse und Wasserwirtschaft-Niederschlag und Abfluss. Internationales Symposium. Informationsberichte Heft 1999,5/99: 127-138, Muenchen. (In German)

32 Blong R, F Siciliano. Postcodes, geocodes and floods. Australian Insurance Institute Journal ,1999, 22(1): 2831

33 Wang R, King L, Jiang T. Flood Vulnerability Analysis and Hazard Management supported by GIS and Remote Sensing - The Jinjiang Flood Diversion Area in Yangtze River Valley, China -. 2nd International Symposium on Operationalization of Remote Sensing .16-20 August, 1999,Enschede: ITC, Enschede

34 Watkins D W, McKinney D C. Recent developments associated with decision support systems in water resources. In: Pielke R. U.S. National Report to International Union of Geodesy and Geophysics, 1991-1994.Washington: American Geophysical Union, 1995

35 Turban E. Decision Support and Expert Systems: Management Support Systems. New York, Macmillan. 1993

36 Andriole S J. Handbook of Decision Support Systems. Tab Publishers. Pennsylvania: Blue Ridge Summit, 1989

37 Menzel L, Niehoff D, Bürger G, et al. Climate change impacts on Advances in Global Change Research. Kluwer, Dortrecht. Boston, London, 2002, (10): 249-269

38 Mauser W, Ludwig R. GLOWA Danube: A research concept to develop integrative techniques, scenarios and strategies regarding global change of the water cycle. In: Beniston M. ed. Advances in Global Change Research, Kluwer, Dortrecht. Boston, London, 2002, (100): 171-188

\section{欧洲洪水影响评价技术在长江流域的运用及其若干修正 Marco GEMMER \\ (Centre for International Development and Environmental Research and Department of Geography, Justus Liebig University, Giessen, Germany)}

摘 要

本文回顾了欧洲洪水影响评价技术. 突出的问题是怎样处理洪灾及如何使洪灾损失降到最低. 很明显 在长江流域开展洪水风险和潜在的损失评价非常有意义. 而现有的欧洲洪水影响评价技术难以在长江流 域直接运用. 我们对其进行了若干修正, 并引入了基于 GIS/RS 的综合水文水动力和最小损失评价模型, 该 模型已经较好地运用于长江流域洪水影响评价的研究项目.

关键词 洪灾 洪水影响评估 洪水淹没范围评估 洪灾损失 损失曲线 最小洪水损失 分类号 P331.1 